\title{
A family study of isolated cleft palate
}

\author{
C O CARTER, KATHLEEN EVANS, REBECCA COFFEY, AND \\ J A FRASER ROBERTS, ANNIS BUCK, MARGARET FRASER ROBERTS
}

From the MRC Clinical Genetics Unit, Institute of Child Health, 30 Guilford Street, London WCIN 1 EH.

SUMMARY A family study was based on 245 boy and 329 girl patients treated surgically for nonsyndromic cleft palate between 1920 and 1939; 86 and 81 respectively were traced and had had children. These 167 were the probands for the family study and were interviewed in their homes. None was born to a consanguineous marriage.

Altogether they had had 384 children of whom 11 had cleft palate $(2 \cdot 9 \pm 0.9 \%)$. They had 398 sibs of whom five had cleft palate, 117 grandchildren of whom one was affected, and 517 nephews and nieces of whom one was affected.

This is the largest series yet available on which to base an estimate of the risks to children of patients with non-syndromic cleft palate. The risk is probably increased where a parent or sib of the proband is affected and increased to a lesser degree where a second or third degree relative is affected. The family patterns in these and other studies suggest that the aetiology of cleft palate is heterogeneous, with some families showing modified dominant inheritance. This is in contrast to cleft lip ( \pm cleft palate) where the data are consistent with a multifactorial threshold model.

There is, as yet, little information on the risks to children of probands with cleft palate unassociated with cleft lip. Furthermore, the studies that are available may include children of affected relatives as well as of probands, or fail to make clear that care was taken to exclude probands who were traced through an affected child. We report a series of 384 children born to 167 non-syndromic probands.

\section{Material and methods}

The material and methods are those described in the companion family study of patients with cleft lip ( \pm cleft palate). ${ }^{1}$ Between 1920 and 1939,245 boys and 329 girls with cleft palate were listed in the surgical registers of The Hospital for Sick Children, London. The success of tracing those who had had children is shown in table 1(a) and (b) and resulted in 86 male and 81 female probands. Those with obvious syndromes were excluded. Since all were survivors and had children, patients with additional severe malformations will also have been excluded. Two probands had presumably coincidental malformations, a man with talipes equinovarus and a woman treated in childhood for pyloric stenosis.

\section{Results}

The main family findings obtained at interview

Received for publication 23 January 1982.
(KAE, RC, AB) in the patients' own homes are shown in table 2 .

One pair of male MZ (examined by COC) twins were both probands. One male proband had a stillborn female co-twin, thought to be unaffected.

Cleft palate was reported and documented in 11 of 384 children, in five of 398 sibs (three documented and two reliable reports from the mother), in one (documented) of 517 nephews and nieces, and in one

\section{TABLE 1(a) Tracing of male probands}

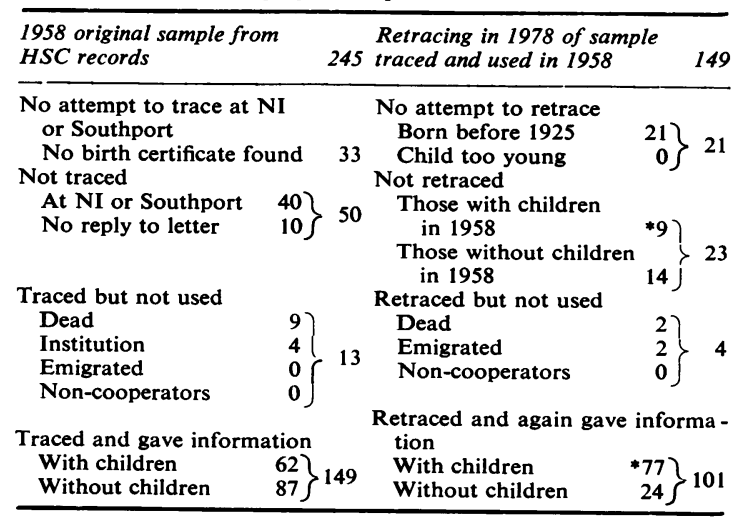

* 86 probands. NI = National Insurance Register.

Southport $=$ National Health Service Register. 
TABLE 1(b) Tracing of female probands

\begin{tabular}{|c|c|c|c|c|}
\hline \multicolumn{2}{|l|}{$\begin{array}{l}1958 \text { original sample } \\
\text { from HSC records }\end{array}$} & \multicolumn{2}{|c|}{$\begin{array}{l}\text { Retracing in } 1978 \text { of sample } \\
329 \text { traced and used in } 1958\end{array}$} & 147 \\
\hline $\begin{array}{l}\text { No attempt to trace } \\
\text { at NI or Southport } \\
\text { No birth certificate } \\
\text { found } \\
\text { Born before } 1930\end{array}$ & $\left.\begin{array}{l}51 \\
83\end{array}\right\} 134$ & $\begin{array}{l}\text { No attempt to retrace } \\
\text { Born before } 1927 \\
\text { Child too young } \\
\text { Only child died }\end{array}$ & $\begin{array}{r}29 \\
* 2 \\
0\end{array}$ & 31 \\
\hline $\begin{array}{l}\text { Not traced } \\
\text { At NI or Southport } \\
\text { No reply to letter } \\
\text { Other }\end{array}$ & $\left.\begin{array}{r}22 \\
7 \\
2\end{array}\right\} 31$ & $\begin{array}{l}\text { Not retraced } \\
\text { Those with children } \\
\text { in } 1958 \\
\text { Those without children } \\
\text { in } 1958\end{array}$ & $\begin{array}{c}* 5 \\
5\end{array}$ & 10 \\
\hline $\begin{array}{l}\text { Traced but not used } \\
\text { Dead } \\
\text { Institution } \\
\text { Emigrated } \\
\text { Non-cooperator }\end{array}$ & $\left.\begin{array}{l}7 \\
5 \\
3 \\
2\end{array}\right\} 17$ & $\begin{array}{l}\text { Retraced but not used } \\
\text { Dead } \\
\text { Emigrated } \\
\text { Non-cooperators }\end{array}$ & $\begin{array}{l}2 \\
2 \\
0\end{array}$ & 4 \\
\hline Traced and gave inforn & ation & $\begin{array}{l}\text { Retraced and again gave } \\
\text { information }\end{array}$ & & \\
\hline $\begin{array}{l}\text { With children } \\
\text { Without children }\end{array}$ & $\left.\begin{array}{l}64 \\
83\end{array}\right\} 147$ & $\begin{array}{l}\text { With children } \\
\text { Without children }\end{array}$ & $\begin{array}{r}* 74 \\
28\end{array}$ & \\
\hline
\end{tabular}

* 81 probands.

(documented) of 117 grandchildren. Two of the original series, who were excluded because they were syndromic, were a patient with the popliteal pterygium syndrome and a patient with the Van der Woude syndrome, each of whom had an affected child.

Other malformations in the children of the probands included one case of cleft lip and one of Hirschsprung's disease. One of the daughters with cleft palate had an ectopic anus and a ventricular septal defect; her mother had only cleft palate. One child was mentally retarded and partially deaf.

None of the probands was born to a consanguineous marriage.

\section{Discussion}

The proportion of children affected $(2.9 \% \pm 0.9)$ was higher, but not significantly, than the proportion affected of sibs of probands $(1 \cdot 3 \% \pm 0 \cdot 6)$. Only one proband had an affected parent. This proband had one unaffected child and no sibs. The proportion of first degree relatives affected was not influenced by the sex of the proband, the proportions, combining sibs and children, being 6/376 for male and 10/406 for female probands.

The proportion of children affected is less, though not significantly, than that estimated by Curtis et $a l,{ }^{2}$ who combined their Canadian data with the original Danish study reported by Fogh-Andersen. ${ }^{3}$ But Curtis et al noted that their figure, six in 103, may be an overestimate, since to get larger numbers they included the children of the probands' affected relatives and thus selected 'familial' cases. It is also less, but again not significantly, than that found in a more recent study from Denmark ${ }^{4}$ in which the probands had 150 children of whom seven were affected. Tables based on the same survey, showing 18 in $169^{5}$ and 18 in $174^{6}$ affected of the children of patients, presumably include 11 affected children of relatives of probands. This Danish study was based on personal interviews with 612 patients 'selected' from an original operation list of 1172 . No details are given of the method of selection, but elsewhere ${ }^{5}$ the authors state that the exclusions were mostly for geographical location or migration, and that the sample was unbiased. However, an important potential source of bias in such studies, which we were careful to avoid, is the tracing of patients, and hence their inclusion as probands, only by the referral of an affected child. In this Danish study, as in the present one, no effect was seen of sex of proband on proportion of children affected (no information is given for sibs). The authors note that this is evidence against a multifactorial model of aetiology with different thresholds for the two sexes, but it is only weak evidence since the sex ratio of cleft palate is about $0 \cdot 6$.

The data are insufficient on which to build hypotheses of the genetic contribution to the aetiology of cleft palate. In contrast to the situation with cleft lip ( \pm cleft palate), where the family patterns are consistent with a multifactorial threshold model, ${ }^{1}$ there are indications of heterogeneity in the aetiology of cleft palate. In the original Danish series ${ }^{3}$ there were three families with three consecutive generations affected with apparently non-syndromic cleft palate, suggesting a major contribution in these three families of a mutant gene with expression in heterozygotes. There were no families in the present series with three consecutive generations affected. Fogh-Andersen also noted that the

TABLE 2 Cleft palate: proportion affected of relatives of probands

\begin{tabular}{|c|c|c|c|c|c|c|c|c|}
\hline & Sons & Daughters & Brothers & Sisters & Nephews & Nieces & Grandsons & $\begin{array}{l}\text { Grand- } \\
\text { daughters }\end{array}$ \\
\hline $\begin{array}{l}\text { Male probands }(86) \\
\text { Female probands }(81)\end{array}$ & $\begin{array}{l}3 / 113 \\
4 / 83\end{array}$ & $\begin{array}{l}1 / 85 \\
3 / 103\end{array}$ & $\begin{array}{l}1 / 96 \\
0 / 117\end{array}$ & $\begin{array}{l}1 / 82 \\
3 / 103\end{array}$ & $\begin{array}{l}0 / 128 \\
0 / 148\end{array}$ & $\begin{array}{l}1 / 115 \\
0 / 126\end{array}$ & $\begin{array}{l}0 / 30 \\
0 / 35\end{array}$ & $\begin{array}{l}1 / 26 \\
0 / 26\end{array}$ \\
\hline \multirow[t]{2}{*}{ Total } & $7 / 196$ & $4 / 188$ & $1 / 213$ & $4 / 185$ & $0 / 276$ & $1 / 241$ & $0 / 65$ & $1 / 52$ \\
\hline & \multicolumn{2}{|c|}{$\begin{array}{c}11 / 384 \\
(2.9 \pm 0.9 \%)\end{array}$} & \multicolumn{2}{|c|}{$\begin{array}{c}5 / 398 \\
(1 \cdot 3 \pm 0.6 \%)\end{array}$} & \multicolumn{2}{|c|}{$1 / 517$} & \multicolumn{2}{|c|}{$1 / 117$} \\
\hline
\end{tabular}


proportion affected of sibs of probands was raised (three in 25) where a relative other than a parent or sib was affected. There is an indication of this effect in the present series. When a second or third degree relative was affected, the proportion affected was two children in 12 (in both instances a cousin was affected), and one sib in 15 (an uncle was affected).

Cleft palate is one of the most readily produced malformations in man by drugs. For example, cortisone, alcohol, folic acid antagonists, and anticonvulsants taken by the mother in the first two months after conception all raise the incidence of cleft palate. However, it is rare to get a history of such exposure in the pregnancies that resulted in patients. The probable complexity of interaction between genetic and environmental factors is illustrated by the work of Fraser and colleagues ${ }^{7}$ on cortisone induced cleft palate in mice. Fraser concludes "we have a situation where many genes contribute to the variance in susceptibility, but relatively few may be involved in a particular highrisk individual".

For the purposes of genetic counselling this series suggests that the empirical risk for children of a patient with non-syndromic cleft palate in Caucasians may be taken as 1 in 40 to 1 in 50 where neither a parent nor a second or third degree relative is affected. The Utah, ${ }^{8}$ two Canadian, ${ }^{2}$ Hungarian, ${ }^{9}$ and two Copenhagen ${ }^{14}$ series indicate a similar 1 in 40 to 1 in 50 risk to sibs where neither parents nor other near relatives are affected. The risk should be increased, both to children and later sibs, where a second or third degree relative is affected and further increased where a parent is affected, perhaps to about 1 in 8 In Japan, though the birth frequency is similar, the proportion of sibs affected is probably rather less than in Caucasians; only about 1 in 100 sibs and, combining two series, only 2 in 124 children of probands were affected. ${ }^{10}$

\section{References}

1 Carter CO, Evans K, Coffey R, Roberts JAF, Buck A, Roberts M. A three generation family study of cleft lip with or without cleft palate. J Med Genet 1982;19: 246-61.

2 Curtis EJ, Fraser FC, Warburton D. Congenital cleft lip and palate; risk figures for counseling. Am J Dis Child 1961;102:853-7.

3 Fogh-Andersen P. Inheritance of hare-lip and cleft palate. Copenhagen: Munksgaard, 1942.

4 Shields ED, Bixler D, Fogh-Andersen P. Cleft palate: a genetic and epidemiological investigation. Clin Genet $1981 ; 20: 13-24$.

5 Melnick M, Shields ED, Bixler D. Studies of cleft lip and palate in the population of Denmark. In: Melnick M, Shields ED, Bixler D, eds. Etiology of cleft lip and cleft palate. New York: Liss, 1980:240.

6 Bixler D. Genetics and clefting. Cleft Palate $J 1981$;18: 10-8.

7 Fraser FC. Animal models for craniofacial disorders. In: Melnick M, Shields ED, Bixler D, eds. Etiology of cleft lip and cleft palate. New York: Liss, 1980:12.

8 Woolf CM, Woolf RM, Broadbent TR. A genetic study of cleft lip and palate in Utah. Am J Hum Genet 1963; 15:209-15.

9 Czeizel A, Tusnady G. A family study of cleft lip with or without cleft palate and posterior cleft palate in Hungary. Hum Hered 1972;22:405-16.

10 Koguelin H. Population data on cleft lip and cleft palate in the Japanese. In: Melnick M, Shields ED, Bixler D, eds. Etiology of cleft lip and cleft palate. New York: Liss, 1980:297-323.

Requests for reprints to Professor C O Carter, MRC Clinical Genetics Unit, Institute of Child Health, 30 Guilford Street, London WC1N 1EH. 